\title{
РАЗРАБОТКА ПОДХОДОВ СИНТЕЗА ПОРФИРИНОВ С ВНЕШНИМИ ХЕЛАТИРУЮЩИМИ ЛИГАНДАМИ ДЛЯ ЦЕЛЕЙ ДИАГНОСТИКИ И ТЕРАПИИ ОНКОЛОГИЧЕСКИХ ЗАБОЛЕВАНИЙ
}

\author{
Ф.Ю. Вяльба, А.В. Иванцова, К.А. Жданова, Н.А. Брагина \\ МИРЭА-Российский технологический университет, \\ 119571, РФ, Москва, пр-т Вернадского, 86.
}

DOI: 10.19163/MedChemRussia2021-2021-521

E-mail:fed-vyalba@yandex.ru

Объединение возможности применения фотодинамической терапии (ФДТ) и магнитно-резонансной томографии (МРТ) в одном тераностическом препарате ещё не нашло клинического применения, но уже привлекает интерес исследователей и имеет большие перспективы в развитии обоих методов [1-2]. На сегодняшний день существует уже несколько подходов для применения порфиринов в качестве контрастных агентов: использование безметальных порфиринов для CEST МРТ (Chemical Exchange Saturation Transfer), использование комплексов порфиринов с парамагнитными металлами и использование коньюгатов порфиринов с лигандами парамагнитных металлов.

В качестве фотосенсибилизаторов, с потенциальным использованием их в качестве тераностических агентов, был получен ряд производных тетрафенилпорфринов типа $\mathrm{A}_{3} \mathrm{~B}$ и транс-А $\mathrm{B}_{2}$, и их металлокомплексы с внешними хелатирующими лигандами на основе 4'-фенил -2,2':6',2-терпиридина для координации металлов большого радиуса (например, GdIII). Полученные соединения были охарактеризованы данными мультиядерной ЯМР-и УФ-спектроскопии, хромато-масс-спектрометрии. В настоящее время проводятся исследования фотофизических, фотохимических и магнитных свойств целевых соединений.
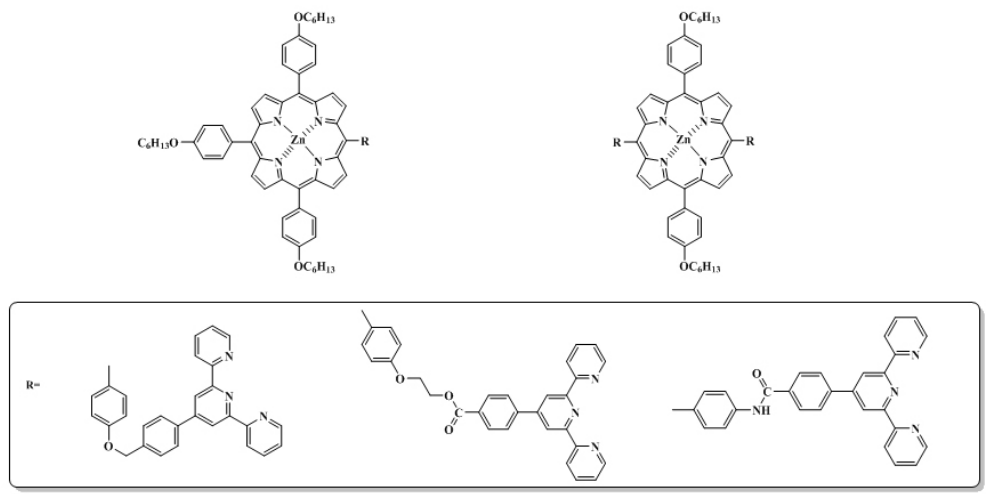

\section{Литература}

[1] Meie He, Yanan Chen, Cheng Tao, Qingqing Tian, Lu An, Jiaomin Lin, Qiwei Tian, Hong Yang, and Shiping Yang, ACS applied materials \& interfaces. 2019, 11(45), 41946-41956.

[2] James T. Brewster II, Gregory D. Thiabaud, Peter Harvey, Hadiqa Zafar, James F. Reuther, Simone Dell'Acqua, Rachel M. Johnson et al. Chem. 2020, 6(3), 703-724. 